\title{
PÁL PERESZLÉNYI AND THE DEVELOPMENT OF MORPHOLOGICAL ANALYSIS IN THE EARLY GRAMMARS OF HUNGARIAN
}

\author{
ANDRÁS CSER \\ Department of Theoretical Linguistics \\ Pázmány Péter Catholic University \\ Egyetem u. 1. \\ H-2081 Piliscsaba \\ Hungary \\ cser@btk.ppke.hu
}

\begin{abstract}
The morphological analysis of Hungarian in the early period of grammatical work was based on three interlaced traditions: Classical Graeco-Roman, Hebrew and German. These were applied to languages that were structurally very much unlike Hungarian. The evolution of morphological analysis was therefore a relatively slow and complicated process, whose milestones discussed in this paper, the four earliest grammars of Hungarian, all represent different stages of development. The grammar by Pál Pereszlényi, which is analysed in some detail here, surpasses the earlier grammars in its acumen on at least three counts: the same set of analytical terms is applied in the description of nominal and verbal morphology; the notions of bound stem and relative stem are clearly recognised; a distinction is made between stems as morphological constituents and word forms serving as starting points of paradigms.
\end{abstract}

Keywords: morphological analysis, agglutination, affixes, stems, Hungarian

This paper focusses on Pál Pereszlényi (1631-1689), grammarian and teacher, priest and member of the Society of Jesus. His work Grammatica Linguae Ungaricae (Grammar of the Hungarian Language, 1682) is one of the early grammars of the language, chronologically the third or fourth depending on how exactly one defines this type of work. Here we shall concentrate on the development of morphological analysis as evidenced by his grammar as compared to his three predecessors, but this is not to imply that his importance lies only in that department. The paper is organised as follows. In $\mathbf{I}$ three topics will be briefly introduced in order to set the context: the general framework in which the gram- 
mar of Hungarian as a scientific endeavour was born and shaped in the 16th-17th centuries; the appearance of morphological analysis in European linguistic work in the same period; and, finally, the most general structural properties of Hungarian morphology, which need to be borne in mind if one is to appreciate the difficulties of adapting the analytical constructs designed for structurally different languages. In $\mathbf{2}$ the morphological analysis of the first three grammarians of Hungarian (János Sylvester, Albert Szenczi Molnár and György Komáromi Csipkés) will be outlined. In 3 Pereszlényi's analysis will be presented in detail. Section 4 concludes the paper.

\section{The context of work on morphology in the 16th-17th centuries}

\subsection{The beginnings of linguistics in Hungary}

Hungarian is one of those languages whose scientific study begins with the early humanistic movement around 1500 and is more specifically interwoven with the new kind of interest in Bible translation and the appearance of the printing press. Typically, the first work on the grammar of Hungarian (Sylvester 1539, see Hegedüs 2008) is actually a school grammar of Latin with substantial discussions of Hungarian parallels and differences between the two languages, plus examples and definitions in Hungarian besides Latin. Also typically, this work submerged in the turmoil of the period and remained unknown until the very end of the 18th century, when it was unearthed as an object of antiquarian interest without any immediate relevance. Those who would publish works on the Hungarian language in the 16th and the early 17th century were usually teachers or ministers trained at one of the German or Dutch protestant universities, eager to participate in establishing the new native forms of (mostly religious) literacy, including Bible-translations, cathechisms, orthographies and dictionaries. Frequently these learned men had no knowledge of each other's work but were at the same time quite aware of what was being done in Germany, France, the Netherlands, Switzerland or Italy. 


\subsection{The birth of morphology in the 16th century}

It is well known that the idea of morphological structure was alien to Antiquity and the Middle Ages. No grammatical unit was recognised apart from the word and the sentence (perhaps the category of phrase was known in some forms of Modistic grammar, see Pinborg 1980). Word forms were described as having grammatical properties, but not as being composed of constituents other than letters and syllables except for certain kinds of prefixation and compounding. Both inflection and derivation were presented as collections of word forms, and although recurrent similarities were noticed they did not lead to the postulation of distinct grammatical units smaller than the word forms. Ancient grammars often relied on a specific word form from which to derive the others and called it the thema, whose original meaning was roughly 'starting point'. For nouns this was the nominative singular, for verbs the first person singular, present tense.

The notion of the radix or root first appeared in European linguistics along with the newly discovered Hebrew grammatical tradition. Reuchlin's celebrated Hebrew grammar and dictionary (Reuchlin 1506) used the traditional term primitivum, but his successors soon adopted the term radix as the equivalent of $\check{s} \bar{o} r \bar{e} s$ (Law 2003, 247-50). This term converged in its use with the traditional thema and the general assumption was that the formal base of a word form was itself a full word. The notion of affixum also comes immediately from the Hebrew grammatical doctrine to denote various kinds of grammatical elements that do not belong to the root. The use of these terms in 16th century European grammars is relatively rare and somewhat inconsistent. The elaboration of the notions stem, root, affix (prefix, suffix) took some time to achieve, but by the 17th century their use is both much more widespread and more consistent.

\subsection{The general morphological properties of Hungarian}

Hungarian, as opposed to the languages spoken in Western Europe as well as Hebrew, is an agglutinating language. This means that stems are mostly invariable, or show only a minimum amount of modification, the fusional exponence of morphological categories is virtually unknown, there are very few bound stem morphemes, and derivation as well as inflection relies heavily on suffixes, lengthy sequences of which can be added 
to stems. Three details in particular need to be noted here. (i) Hungarian employs a relatively large number of structurally similar nominal suffixes to express both what is expressed morphologically (if at all) in Latin and many European langauges (e.g., dative, accusative), and much of what is expressed with the help of prepositions. (ii) Verbs distinguish between a definite and an indefinite paradigm in all moods and tenses, composed of two almost totally disjunctive sets of suffixes, whose use is governed by the presence vs. absence, and in the former case the definiteness vs. indefiniteness, of the object. (iii) Personal endings occur not only with verbs, but also with nouns, postpositions and nominal case endings: ${ }^{1}$ látt-am 'I saw', ház-am 'my house', után-am 'after me', ról-am 'about me' (for the last item cf. a ház-ról 'about the house'; the case ending functions in structures like rólam as a stem).

These properties set Hungarian into a marked contrast with languages such as Latin, for which the European grammatical apparatus and terminology was worked out in the first place, German, whose emerging grammatical tradition strongly influenced work on Hungarian grammar, and Hebrew, whose grammatical tradition first supplied the technical details (albeit only after substantial transformations) of morphological analysis. The fundamental difference between the morphological character of Hungarian and the languages whose grammatical traditions were adapted to analyse it took quite some time to resolve. This was all the more so since the motivation to actually free Hungarian grammar from the inherited framework was not particularly strong: these grammars were written either with the intention of serving as introductions to the study of Latin at schools or for prospective learners whose acquaintance with the classical tradition (and sometimes with Hebrew) was taken for granted. However, in this process of adapting the framework of morphology to the specific structure exhibited by Hungarian the great seventeenth-century grammarians made remarkable progress.

${ }^{1}$ Throughout the paper we use hyphens to indicate the morphological composition of Hungarian words. They are not part of the orthographic representation. 


\section{Morphological analysis before Pereszlényi}

\subsection{János Sylvester: Grammatica Hungarolatina (1539)}

Sylvester has no morphology in the strict sense: in his grammatical description only full word forms are found, to which particles or affixed pronouns can be added. Apart from these two, words are simply declined or inflected, i.e., they exhibit formal variation, but no segmentation into stems and suffixes is assumed. Affixed pronouns (pronomina affixa) are very much in the focus of Sylvester's attention. By this term he denotes those personal endings that occur both on verbs and nouns (cf. láttam and házam above; not his actual examples); he does not discuss the postpositional structures or those involving suffixes-turned-stems (utánam and rólam, respectively). Affixed pronouns are important for Sylvester because they, as he sees them, provide a clear instance of structural similarity (for him: affinitas 'relatedness') between Hebrew and Hungarian, a major point of pride for Hungarian scholars in Humanism as well as later. It is further cursorily mentioned that prepositions "are sometimes postposed" in Hungarian, as in az házban 'in the house'.

Sylvester's "morphology" thus involves three kinds of forms: (i) inflection, i.e., formal variety with no morphological constituents assumed (e.g., szeretek 'I love', szeretsz 'you love', both indef); (ii) full words combined with affixed pronouns (e.g., szeret-em 'I love def', szeret-ed 'you love def', süv-em 'my brother-in-law', süv-ed 'your brother-in-law); these could be analysed as full word forms with an affixed pronoun added because, as it happens, the nominative singular for nouns as well as the 3rd person singular present indefinite for verbs is a zero-suffix form; (iii) full word forms with particles added (szeretek vala 'I used to love').

\subsection{Albert Szenczi Molnár: Nova grammatica ungarica (1610)}

Molnár has a broader repertoire of terms for morphological structure and devotes much more explicit discussion to all matters including morphology, but his use of the terms at his disposal is rather inconsistent. Nominal and verbal morphology are treated differently, though there is overlap in the terminology of the two fields.

In nominal morphology the starting point is the Latin six-case system, which Molnár augments with an additional case he calls mutativus (emberré '[become, turn into a] man' etc.). The personal endings that 
nouns take are affixed pronouns (pronomina affixa or affixum pronominale) for him just like for Sylvester (whose work was unknown to him), but he is completely silent about the identity of these to a subset of verbal endings. The reason for the absence of this generalisation is in all likelihood not that it escaped his attention but that he realised that the nominal personal endings are identical to the definite verbal endings in the singular and the 3rd plural but to the indefinite endings in the remaining two forms of the plural - a structural mismatch that had lead to palpable confusion in Sylvester's grammar. Molnár's treatment of the rest of nominal inflection appears to involve postpositions (the házról-type, i.e., forms in which something that corresponds to a Latin preposition is attached to the end of a noun), but on closer scrutiny, the picture is rather incoherent.

Already in the discussion of the case system he simply lumps together all the Hungarian case forms that do not correspond to Latin cases under the rubric of the ablative case (book I, chapter 10). Unlike to the Latin-like case endings, such as the accusative or the dative, he refers to these as affixes (affixa). Further on, in the section on the possessive structure (involving agreement in Hungarian rather than case forms) he says "I call ablative all the cases that have an affixed pronoun in spite of the fact that this pronominal or affixive case is inflected through the six ordinary cases" (book II, chapter 3, translation ours). The notion of case is obviously stretched beyond necessity in this use. The same personal endings are referred to elsewhere as affixed prepositions (praepositiones affixas, book 1, chapter 17 on compounds), yet elsewhere as particulae (book II, chapter 1, where the rólam-type construction is discussed). The latter term (particula) is used in the traditional sense, i.e., to collectively denote the indeclinable parts of speech (prepositions, adverbs, interjections and conjunctions). But it is also used for morphological elements that do not fit into the case system and also cannot be equated with Latin prepositions (e.g., the superlative prefix leg- or the derivational adjectival suffix -talan 'un-'). At the same time the productive adverbial forms ending in -ul/ül (e.g., latinul 'in Latin') are cursorily labelled by Molnár as adverbial or assimilative case in a note appended to the section on the case system. In the discussion of derivation he mostly does not use any term to refer to the suffixes, though occasionally the completely neutral expression terminatio 'ending' - inherited from Antiquity and referring simply to the final letters of any word - is found. 
It is only in the discussion of verbal morphology that the terms root (radix) and stem (thema) are encountered. They are used very sparsely, and apparently as synonyms; they denote the present 3rd person singular form, which is indeed the only zero-suffixed form of verbs. Molnár makes a point of stressing that this is very similar to Hebrew, where the same (in fact, the 3rd person singular masculine perfect) form is the starting point or root of verb forms (book 1, chapter 18, but also in the foreword). The term particula is used for suffixes like -hat/het 'may, can'; the invariable form volna (used for past conditional) is called an auxiliary verb (auxiliare verbum).

\subsection{György Komáromi Csipkés: Hungaria Illustrata (1655)}

Komáromi, who was well versed in the Semitic languages, distances himself explicitly from the classical tradition and stresses the Eastern character of the Hungarian language throughout his short grammar. His morphological analysis appears at first sight to employ the term affixum in a consistent and general fashion, though radix and thema occur rarely in it: "motio nominis e singulari numero in pluralem, fit affixo $k$ ipsi themati ut ember emberek lov lovak ház házak" "the movement of a noun from the singular number into the plural is with (the addition of) the affix $k$ to the stem itself, as in ember emberek ('man men') lov lovak 'horse(s)' ház házak 'house(s)'. ${ }^{2}$ At the same time, affixes are also referred to as terminatio, character and syllaba characteristica.

In the discussion of verbal morphology, the consistency of segmentation seems to give way to an unnecessarily complicated system of formal variation. As Komáromi explains, verbal conjugation makes use of three devices: (1) affixa pronominalia, as in verem, verjük 'I/we beat'; these endings he also calls suffixa; (2) vocalium mutationes (vowel change), as in verem verém 'I beat pres vs. past'; (3) epenthesis vocalis vel syllabae (insertion of a vowel or a syllable), as in kérlek $\rightarrow$ kérélek, kértelek, kérjelek 'I ask you pres $\rightarrow$ past1, past2, subj'. This appears to be based on the assumption that sequences of suffixes are ruled out (in sharp contrast to the actual morphological character of Hungarian). In fact, the

${ }^{2}$ Note that the form lov for 'horse' is not a free form; the unsuffixed nominative is ló. In this instance, Komáromi's use of the term thema is already removed from its original meaning and approaches a stricter sense of 'stem'. Nevertheless, given the sporadic occurrence of thema in his grammar this can hardly be seen as genuine innovation. 
three devices of affixation, vowel change and epenthesis are those found in traditional accounts of Semitic morphology, without doubt the single most important inspiration for Komáromi, who strove to make Hungarian appear as similar to Hebrew as was possible.

\section{Pál Pereszlényi}

\subsection{His life}

Pereszlényi was born in 1631, in one of the counties (Hont) of that part of Hungary which then belonged to the Habsburg Empire and is now part of Slovakia. He joined the Jesuit order at the age of 19 and after completing his formation and studies was assigned the task of teaching Hebrew, Biblical studies, theology, and preaching in Slovak to the local population. The only work by him that has appeared in print is his grammar published in 1682 by the Jesuit university (the only university in Hungary at the time) in what was then called Nagyszombat in Hungarian, Tyrnavia in Latin and is Trnava in Slovak. He is not known to have written anything else. He died in 1689, having had a life which was apparently full of a priest's duties and interests and which little else than what has been summarised here is known about.

\subsection{The Grammatica Lingva Ungarica (1682)}

\subsubsection{Preliminaries}

The title page of the book ${ }^{3}$ is inscribed Grammatica Lingva Ungarica. A P. PAULO PERESZLENYI è Societate Jesu. Juxta hanc methodum concepta ac elaborata. Et permissu Superiorum typis data. Tyrnaviæe, Typis Academicis, Excudebat Matthias Srnensky, 1682; that is, Grammar of the Hungarian Language by father Paulus Pereszlényi of the Society of Jesus. Conceived and elaborated by this method. Printed with the permission of the superiors in Tyrnavia. At the University print shop, typeset by Matthias Srnensky, 1682. The book appears to be quite clearly based

\footnotetext{
${ }^{3}$ We used one of the two copies in the University Library, Budapest. By the time the present paper was all but finished, a facsimile edition with translation was published by Zsuzsa C. Vladár (= Pereszlényi 2006). Vladár used another copy of the same 1682 edition (found in the National Széchényi Library), which includes a supplement not found in the copy that we used.
} 
partly on Szenczi Molnár's grammar, though this is not stated explicitly anywhere in it, partly on Alvarez's grammar of Latin, the standard work for Jesuit colleges all over the world - this is what the expression by this method (juxta hanc methodum) refers to in the title.

The Portuguese Jesuit Emmanuel Alvarez's De institutione grammatica was first published in 1572 in Lisbon. It was submitted to detailed discussion on several levels within the Society of Jesus and, after being refashioned with an eye to the innovative didactic concerns of the Society, it was republished in 1584 . Throughout the seventeenth century it was published in several parts of the Catholic world, often updated and adapted to local needs, and thus remained a high quality, standardised work for Jesuit schools everywhere. It appeared in print in Hungary as well: seventeenth-century editions published in Nagyszombat (Tyrnavia), Lőcse (Leutschovia) and Kolozsvár (Claudiopolis) are known. It is all the more remarkable that the latter two print shops were protestant.

\subsubsection{The structure of the book}

Pereszlényi's Grammatica consists of four parts: I De nomine (On the noun), II De pronomine (On the pronoun), III De verbo (On the verb) and IV De syntaxi (On syntax). To these an appendix with the title Praxis is added, which is a series of exercises that teach the amplification of sentences. Part I begins with the discussion of letters/sounds and some phonological phenomena relevant to morphology. The presentation is concise but incorporates a fair amount of important and acute observations. After the traditional "Littera" section, the nominal properties are introduced. In line with the Latinate tradition, a six-case system and three genders are assumed, though Pereszlényi explains that gender is not formally marked either by ending or by the article. He then moves on to the detailed presentation of nominal declensions (in the six-case system), more precisely to what he calls "pure declensions", i.e., those of nouns lacking the personal endings. A concise but very detailed description of vowel harmony is included here, and so is the declension of the pronouns $a z, e z$ 'that, this', called article by the author ( $a z$ indeed coincides with the definite article, though the latter is indeclinable). Some space is devoted to an unusually meticulous discussion of the vowel before the accusative suffix - $t$, ever since a crux of Hungarian morphophonology. The rest of nominal morphology includes the types of derived nouns and adjectives in a Donatus-inspired classification, the comparison of adjectives, and finally numerals. 
Part II begins with the classification of pronouns, then presents their declensions. The discussion of the affixed pronouns, i.e., the personal endings, and of the corresponding possessive pronouns proper (the enyém 'mine'-type) takes up a substantial part of this section of the book. Pereszlényi refers to the corresponding Hebrew forms, which, as indicated above, are structurally parallel (if only in part) to these Hungarian endings, and which thus became a central concern for all early grammarians of this language. We shall return below to the highly detailed description of possessive suffixation that Pereszlényi gives on these pages.

Part III begins with the explication of the grammatical properties of verbs: mode, tense, person, number and conjugation. The last of these categories involves the indefinite-definite as well as the active-passiveneutral distinctions, of which the latter can only be applied to the grammar of Hungarian with a certain amount of artificiality. After explaining what the root of a verb is (again see below), there follow lengthy paradigms with explanatory notes on the formation of the various verbal categories and individual forms. This includes a detailed presentation of active, passive, reflexive, definite, indefinite and factitive formations, all coming of course in combinations and with overlaps, which does not make it easy to set up a neat classification of the verbal system. ${ }^{4}$ By the standards of the period Pereszlényi accomplished this task with comparative consistency. At the end of Part III anomalous verbs are presented as are the translations of Latin expressions involving the verbs habeo 'have' and debeo 'must, have to'. The latter two are discussed because their Hungarian translation equivalents are structurally different from the Latin expressions, there being no Hungarian verb for 'have' and there being only an impersonal verb for 'must'. An Appendix on metaplasmus concludes the morphology, including a traditional collection of phenomena like prosthesis, metathesis, and so on.

Part IV has no general introduction, despite the shift to a new level of grammar. The discussion of syntax falls into six chapters arranged, by and large, according to the parts of speech. Chapter 1 includes the constructions into which nouns, adjectives and pronouns (in the classical sense) enter: possessive structure, noun and modifying adjective, the correspondence between relative pronoun and its antecedent, and that between a question word and the response to it. Chapters 2-4 are on constructions involving government by verb. Chapter 2 is organised around verbal cat-

${ }^{4}$ A detailed description of Pereszlényi's verbal system is found in Vladár (2001). 
egories (active, passive, neutral, impersonal, infinitive, the equivalents of the Latin gerund and the supine); 3 is about the expression of locational relations with verbal complements (rest in a place, motion from, to and through a place); 4 is a motley collection of constructions and translation equivalents, not all of which involve verbs, ranging from the ablative of instrument to dimensional adjectives. Chapter 5 is a discussion of "prepositions", i.e., of the nominal case suffixes as well as certain other kinds of words that can, from some point of view, be regarded as prepositions (like közel 'close (to sg.)'). The last chapter (6) promises in its title a presentation of constructions involving adverbs, interjections and conjunctions but is, in fact, nothing more than a survey of the derivation of adverbs. ${ }^{5}$

\subsubsection{Pereszlényi's morphological analysis}

\subsubsection{Nominal and pronominal morphology}

As said earlier, the starting point in the discussion of the inflectional morphology of nouns, adjectives and pronouns is the six-case Latin declension. The endings typical of the cases are usually referred in the Grammatica as terminationes, sometimes as affixa. ${ }^{6}$ As mentioned earlier, terminatio had been traditionally the neutral term for the ending of any linguistic form irrespective of its grammatical status. It is significant that Pereszlényi only uses it with reference to suffixes, and it is perhaps even more significant that - although he hardly uses this term elsewhere in his book-another occurrence of terminatio refers to a suffix that can be followed by further endings (hattyú-i, hattyú-i-m etc. 'his swans, my swans', where the $-i$ - is the plural marker; Pars II, cap. $3, \S 3$ ). In this use terminatio refers to something that is a separable morphological formative and, importantly, is not necessarily found at the end of a word form.

While Pereszlényi presents the outlines of nominal morphology in terms of the six-case declension, he is nevertheless clearly aware of the relevant differences between Latin and Hungarian, even if the organisation of the entire work and also the wording obscures this at first sight. He makes clear at the outset that Hungarian plural "case" forms, as opposed

5 The missing topics were covered in a supplement a few years later, which was then added to some, but not all, of the copies of the 1682 edition, and was not included at all in the two subsequent editions. On the questions surrounding the supplement see Pereszlényi ([1682] 2006, 12).

${ }^{6}$ In the first lines of the relevant chapter (Pars I, cap. II, §1) literae 'letters' and syllabae 'syllables' also occurs, but these are quickly replaced by the terms above as the exposition unfolds. 
to their Latin counterparts, have endings that are simple concatenations of the plural suffix and the singular case suffix: ${ }^{7}$

"Nota omnem declinationem fieri additis Nominativo (cui Vocativus est similis) quibusdam literis, aut syllabis, \& omnino eædem terminationes serviunt pro Numero plurali, quæ pro singulari...

Formato semel Nominativo Plurali, manet is per omnes Casus, assumptis affixis..."

(Pars I, cap. II, $\S \S 1$ and 7)

Important pieces of information regarding nominal morphology are relegated to Part IV (on syntax), e.g., the observation that in Hungarian there is no structural difference between those case endings that correspond to Latin case endings and those that functionally or semantically correspond to Latin prepositions. This is what the following passage explains. ${ }^{9}$

"Alia verba, quae apud Latinos praeter casum Accusativum, etiam alios casus admittunt... casus illos alteros efferunt beneficio affixae praepositionis illius, in quam casus ille resolvi fere possunt, nam aliqua salva Latini sermonis lege, Latine in eas praepositiones, \& casus r[e]solvi nequeunt: porro praepositio quaecunque affigitur vocibus in recto sumptis cujusvis numeri.

Verbi gratiâ: verba accusandi, monendi, casum Latinum alterum, seu rei efferunt cum sequentibus affixis ról, ről, rúl, rül, quae Latine significant de ut Joseph bé vádolá a' battyait fölötte gonosz bűnről. . . Intlek erről. . .

Verbum demonendi easdem praepositiones habet, sed aliâ significatione, nimirum $a$ vel $a b$, ut Le intlek arról demoneo te ab ea re.

Verba damnandi, aestimandi, docendi casum rei efferunt cum affixis ra, re ut Igen rút halálra kárhoztass[u]k ötet..."10 (Pars IV, cap. 2, §1)

7 See also the previous note.

${ }^{8}$ Note that all declensions are formed with the addition to the nominative (to which the vocative is similar) of certain letters or syllables, and altogether the same endings serve for the plural number as for the singular...

Once you have formed the nominative plural, it remains the same through all the cases, and takes suffixes...'

9 The inconsistent italicisation follows the original (Pereszlényi 1682).

10 'Other verbs which for the Latins admit other cases besides the accusative... express those other cases [in Hungarian] with the help of that affixed preposition into which that [Latin] case can be usually resolved [i.e., paraphrased in Latin]; because, in conformity with the rule of Latin speech, some cannot be resolved in Latin into those prepositions and cases; then any preposition [in Hungarian] is attached to the words taken in the nominative of either number.

Acta Linguistica Hungarica 55, 2008 
This somewhat cumbersome text can be interpreted as follows. Many verbs are unproblematic when compared in Latin and Hungarian because they govern the accusative in both languages, such as see, hit or kill. But many verbs govern the remaining three oblique cases in Latin (genitive, dative, ablative), while the Hungarian counterparts of the same verbs govern a form of the noun that is not the same as the translation equivalent of the relevant Latin case. For instance, verbs expressing accusation, recrimination, judicial sentence, absolution and the like tend to take the genitive in Latin (accusatur proditionis 'he is accused of treason'), but not in Hungarian. Pereszlényi finds it helpful that some of these verbs also occur in Latin with a preposition (accusatur de ambitu 'he is accused of bribery'), i.e., the case can be "resolved" into a preposition. The Hungarian translation equivalent can thus be regarded as a word form involving what corresponds to the Latin preposition rather than to the case, but the preposition in Hungarian is affixed to the end of the stem. The "resolution" into a prepositional structure is, however, not always possible, hence the qualification fere, here translated as usually; and it is to this usually that the following because refers (because, in conformity with the rule of Latin speech, some cannot be resolved in Latin). It is somewhat surprising that Pereszlényi also mentions resolution into cases (some cannot be resolved in Latin into those prepositions and cases); perhaps what he had in mind was that some of the "problematic" Latin cases had well-formed variants with the "unproblematic" accusative (meminit prceteritorum 'he remembers the past' with genitive, but also meminit hac 'he remembers those (things)' with the accusative).

When explaining the Hungarian examples that follow the introductory exposition, Pereszlényi simply calls all the endings in these examples affixes (verbs of accusing, warning express the Latin second or genitive case with the following affixes ról, ről, rúl, rül... ${ }^{11}$ Verbs of sentencing,

To take exampes from verbs: verbs of accusing, warning express the Latin second or genitive case with the following affixes ról, röl, rúl, rül, which in Latin mean de ('about'), as in Joseph bé vádolá a' battyait fölötte gonosz bünröl ('Joseph accused his brothers of a horrid crime')... Intlek erröl ('I warn you about this')...

A verb of warning against something has the same prepositions, but with a different meaning, especially [with the meaning of] $a$ or $a b$ ('from, by'), as in Le intlek arról ('I warn you against that').

Verbs of sentencing, evaluating and teaching render the genitive case with the affixes ra, re ('onto'), as in Igen rút halálra kárhoztass[u]k ötet 'Let us sentence him to an ignoble death'...'

11 The four variants are due to dialectal difference (-ról, -ről vs. -rúl, -rúl) as well as vowel harmony (-ról, -rúl vs. -röl, -rül).

Acta Linguistica Hungarica 55, 2008 
evaluating and teaching render the genitive case with the affixes ra, re...). The fact that the term preposition turns up in the middle of the examples with reference partly to the same suffixes (a verb of warning against something has the same prepositions) does not detract from the importance of this step forward: after significant detours which result from thinking in terms of translation equivalents - a practical necessity for a teacherPereszlényi arrives at the conclusion that all nominal (inflectional) endings in Hungarian are specimens of the same linguistic category, called affixum.

In pronominal morphology, the part that is of importance to us now is that on affixed pronouns (De affixis pronominibus, quae latinis pronominibus possessivis aquivalent i.e., On affixed pronouns, which correspond to Latin possessive pronouns, Pars II, cap. III). These had been, ever since Sylvester (see 2.1), in the focus of grammarians' attention. Pereszlényi analyzes the personal endings called affixed pronouns along the lines of Szenczi Molnár's Nova grammatica: in a possessive structure the noun separates the two halves of what we could call "real" possessive pronouns: enyém 'mine' + könyv 'book' $\rightarrow$ én könyv-em 'my book', where enyém is cut into two and the noun könyv is inserted between the two parts. ${ }^{12}$ As with nominal inflection, in the initial formulation of this regularity Pereszlényi refers to syllables and letters, but later on uses the term affixum (occasionally terminatio) for the personal endings fairly consistently. Importantly, the term thema for 'stem' also turns up in this section, if only marginally. The following excerpts from the lengthy exposition serve as illustrations.

"... dividunt ea interposito substantivo ita, ut inter personales syllabas et finales litteras medium locum teneat substantivum. .

...sunt, quae in vocalem exeunt, ut Alma, lakó, hattyu. Et habent tertiam singularem cum affixo. Almája, lakója, hattyúja.

His pro formando Numero plurali demes literam finalem $a$, \& litera $i$, quae remansit erit formativa substanti[vi] pluralis cum affixo possessivo; efficitque illud $i$ per se syllabam sic: Almái... lakói... hattyúi

Vel sunt Nomina illa desinentia in Consonantes, ut Rab, dob. Et habent in tertia singulari $j a$, ut rabja, dobja.

His addes literam $i$, formativam Nominis substantivi pluralis, cum affixo singulari, habebisque Rabjai... dobjai..."13 (Pars II, cap. 3, §3)

${ }^{12}$ In the structure én könyvem the first word én is ' $\mathrm{I}$ ', the personal pronoun in the nominative. It can usually be present in the phrase for emphasis, but the form könyvem is grammatical (and, actually, much more frequent) without it. 


\subsubsection{Verbal morphology}

After a general description of verbal categories, the morphological analysis of verbs begins with the explication of the notion of the root:

"Radix, seu fundamentum conjugationum est tertia persona cujusvis verbi regularis primæ conjugationis... In verbis Neutris quae tertiam personam habent in $i k$, facies pro radice tertiam personam fictam, abjecto $i k$, ut játzom ludo, abjecto $m$ et præcedente illud vocali $o$, manebit játz, hoc ultimum quidem est imperfecta persona tertia, quoad significationem: et completur addito $i k$, játzik ludit; sed pro radice est ita accipiendum.

Aptissime tamen hæc tertia persona ponitur pro radice formationum, quia brevissima est, et fere in omnibus modis, temporibusque continetur, ob quam causam etiam Hebræi pro radice ponunt tertiam personam." 14

(Pars III, cap. I, §2)

This explanation is based on the fact that the third person singular indefinite in Hungarian has a zero ending for most verbs (lát 'he sees', letöröl 'wipe off' etc.). Many verbs, however, have an -ik ending instead of zero (e.g., játsz-ik 'he plays'); the root of these verbs, then, is not the same as the third person singular indefinite form. For these, as Pereszlényi says, a "virtual" or "incomplete" third person (in modern terms a

${ }^{13}$ ،... with the noun inserted they divide [the possessive pronouns] so that between the personal syllable and the final letters the noun takes the middle place...

...some end in a vowel, like alma ('apple'), lakó ('inhabitant'), hattyu ('swan'). And they have the third person singular with the affix: almája ('his apple'), lakója ('his inhabitant'), hattyúja ('his swan').

To form the plural number, take away from these the final letter $a$, and the letter $i$, which remains, will be the formative of the plural noun with a possessive affix; and this $i$ forms a syllable on its own like this: almái ('his apples')... lakó $i$ ('his inhabitants')... hattyúi ('his swans').

Or there are those nouns that end in consonants, like rab ('prisoner'), dob ('drum'). And in the third person singular they have $j a$, as in rabja ('his prisoner'), dobja ('his drum').

To these add the letter $i$, the formative of the plural noun, with a singular affix, and you will have rabjai ('his prisoners')... dobjai ('his drums')...'

${ }^{14}$ 'The root or the basis of conjugations is the third person of any regular verb of the first [i.e., indefinite] conjugation... In neuter verbs that have a third person in $-i k$, make a virtual third person for root by removing the $i k$, as in játszom 'I play', by removing the $m$ and the vowel $o$ that is before it, what remains is játsz; this latter is an incomplete third person as regards meaning: and it is completed with the addition of $i k$, [as in] játszik 'he plays'; nevertheless it has to be taken like that as a root.

It is most suitable that this third person is posited as the root of formations, since it is the shortest, and is mostly included in all moods and tenses, and it is for this reason that the Hebrews posit the third person as a root.' 
bound morpheme) has to be formed as a root. It is a little surprising that after explaining this he derives such a virtual root from a first person, rather than a third person, form (játszom $\rightarrow$ játsz-), but the result is, of course, the same. The introduction of bound roots into Hungarian grammar is again a significant accomplishment (and a non-obvious one, given the agglutinating nature of the language, see 1.3); Szenczi Molnár, on whose grammar Pereszlényi greatly relied, simply calls the third person singular the root but does not appear to have moved in the direction of a more abstract (and therefore perhaps more adequate) notion of a morphological base form.

What follows in the book at this point is the introduction to the extensive tables that present the verbal endings. Pereszlényi says the following:

"Omnis variatio per modos, tempora, \& numeros personasque fit ope affixarum terminationum, quæ ideo affixa vocabuntur...

Affixa quae formant tempora, personas, \& numeros, ponuntur in tabellis affixorum ante singulas Conjugationes." 15 (Pars III, cap. I, §3)

The discussion of passive formations is again noteworthy. The introductory explication begins as follows:

"Passivum verbum formatur a tertia persona singulari conjugationis primae, seu verbi indeterminati activi, v.g. olvastatom legor, ab olvas, szerettetem amor a szeret; additâ syllabâ vocis passivæ formativâ pro prima classe tat \& pro secunda tet, fiet olvastat, szerettet; ista sint tibi themata conjugationis passivæ, quæ deduces per affixa sequentis Tabellæ...

... quæ ante finalem thematis literam $t$, habent consonantem, ut szánt. . . excludunt primum $t$ affixi, ut szántat..."16 (Pars III, cap. IV)

${ }^{15}$ 'All variation through the moods, tenses, numbers and persons is made with the help of affixed endings, which will therefore be called affixes...

The affixes that form the tenses, persons and numbers, are arranged in the tables of affixes before each conjugation.'

${ }^{16}$ 'A passive verb is formed from the third person singular of the first conjugation, or of the indefinite active verb, e.g., olvastatom 'I am read' from olvas 'he reads', szerettetem 'I am loved' from szeret 'he loves'; with the addition of the formative syllable of the passive word form tat for the first class and tet for the second, it will be olvastat, szerettet; let these be the stems of the passive conjugation for you, which you derive with the affixes of the following table...

... those [verbs] that have a consonant before the final letter $t$ of the stem, like szánt ('to plough')... exclude the first $t$ of the affix, as in szántat ('is ploughed')...' 


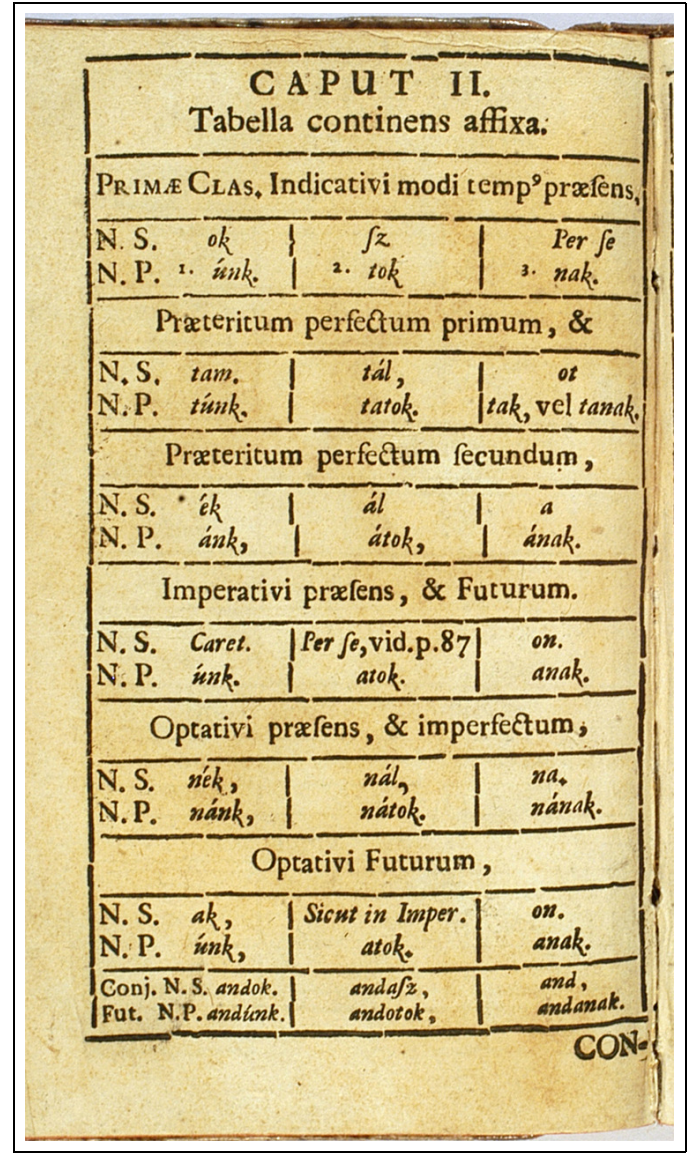

Fig. 1

What is especially important here is the appearance of the notion of a relative stem, in this case a stem consisting of the absolute stem and the affix of the passive, which is then the base of the passive conjugation. The same is referred to as root in the discussion of the factitive conjugation:

"[Verbum mandativum] a passivo fit, si radici vocis passivæ, v. g. olvastat, szerettet, superaddas aliam syllabam tat vel tet, ut olvastattat curat legi, szerettettet curat amari..."17

(Pars III, cap. IV)

17 '[The factitive verb] is from the passive, if to the root of the passive form, e.g., olvastat, szerettet, you add another syllable tat or tet, as in olvastattat 'he has something read', szerettettet 'he has someone loved'.' 


\section{Conclusion}

The morphological description of Hungarian shows considerable progress from the beginning of the 16th century to the end of the 17th. Pál Pereszlényi's work is an important milestone in the process of adapting a framework designed to describe three structurally very different languages, viz. Latin, German and Hebrew, to the analysis of Hungarian while building on the work of his most eminent predecessor, Albert Szenczi Molnár. Pereszlényi's significance and novelty can be summarised in the following points:

- He was markedly consistent, as compared to his predecessors, in applying the same set of analytical terms in the description of nominal and verbal morphology.

- He very clearly grasped the notion of bound stem as well as relative stem.

- As a consequence, he was able to distinguish stems as morphological constituents from word forms serving as starting points of paradigms (thema in the traditional sense).

It is true that Pereszlényi's work still relied heavily on the Latinate tradition in ways that do not seem appropriate to the modern reader (cf. the six-case nominal paradigm) - the reasons for this were given in 1.3. It is also true that his terminology is really neat only when compared to his own contemporaries and those who went before him. In both respects, much work remained to be done until the nineteenth century. But in historiography, the protagonists and their achievements must be understood and evaluated in their own contexts and against the background of their own times; and, in that perspective, Pereszlényi's work is indeed outstanding.

\section{References}

Hegedüs, József 2008. Johannes Sylvester's grammatical legacy (1539) and its European background. In: Acta Linguistica Hungarica 55 : 41-57.

Komáromi Csipkés, György 1655. Hungaria illustrata, hoc est brevis sed methodica naturæ et genii linguæ Hungaricæ explicatio. Utrecht.

Law, Vivien 2003. The history of linguistics in Europe from Plato to 1600. Cambridge University Press, Cambridge. 
Pereszlényi, Pál 1682. Grammatica Lingvæ Ungaricæ. Tyrnavia.

Pereszlényi, Pál [1682] 2006. Grammatica linguæ ungaricæ. A magyar nyelv grammatikája. Facsimile edition with a translation by Zsuzsa C. Vladár. Magyar Nyelvtudományi Társaság, Budapest.

Pinborg, Jan 1980. Can constructions be construed? In: Historiographia Linguistica $7: 201-10$.

Reuchlin, Johannes [1506] 1974. De rudimentis hebraicis libri III. Facsimile edition. Olms, Hildesheim \& New York.

Sylvester, János [1539] 1989. Grammatica Hungarolatina. Facsimile edition (Bibliotheca Hungarica Antiqua 22). MTA Irodalomtudományi Intézet, Budapest.

Szenczi Molnár, Albert [1610] 2004. Novæ grammaticæ ungaricæ libri duo. Új magyar grammatika két könyvben. Facsimile edition with a translation by Zsuzsa C. Vladár. Magyar Nyelvtudományi Társaság, Budapest.

Vladár, Zsuzsa C. 2001. Pereszlényi Pál nyelvtanának terminusairól [On the terminology of Pál Pereszlényi's grammar]. In: Magyar Nyelv 97 :467-79. 